\title{
Libraries and Access to Information In Palestine
}

Impacts of Military Occupation

Deanna K. Roberts, Union Theological Seminary

ABSTRACT Life under occupation, for over 70 years, has had a major impact on Palestinian libraries, their function within communities, and access to materials and resources that most libraries in other places around the world do not experience. This paper will give a brief overview of several libraries within Palestine, including a historical narrative about the history of the Israel/Palestine conflict. Also included are snapshots of a few libraries within Palestine, the experiences of a few librarians living and working in the West Bank and Gaza, and a summary overview of the documentary film The Great Book Robbery by Billy Brunner. This paper has previously been published as a chapter within an open access resource titled International Libraries: An Open Textbook.

\section{COUNTRY PROFILE}

Since 1948, Palestine has been an occupied land under military control by the modern State of Israel. Palestine's categorization as an independent nation-state is a complicated and contested issue because it is not a recognized country, nor a region-it is a territory comprising three cut-off locations, the West Bank, Gaza, and East Jerusalem (Lefebvre-Danset 2009, 322). For more than 70 years, the apartheid system of repression that Israel has inflicted on Palestinians has caused their economic and social structures to collapse. Librarians in the occupied territories work endlessly to ensure that the once vibrant Palestinian culture remains active and does not become a distant memory. Collecting and curating materials that speak to the past presence and current living of Palestinians in the historic land of Palestine is, in itself, an act of resistance. However, this is increasingly difficult as the normalization of the seizure of books, confiscation of supplies, limited budgets, and "security" checkpoints continues. With increased "security" measures by the State 
of Israel, the daily lives of Palestinians become more confined each day. One reason why the Jewish state feels a need to protect itself is because of the decades-long narrative that Arabs are terrorists.

Much of Israeli media and academia have characterized the Palestinian resistance movement as a key factor in the global history of terrorism. The role of the academics to validate this depiction with 'scientific' research that both recorded acts of Palestinian violence and proved the applicability of theoretical definitions of terrorism to these acts. Israeli politicians and the media fully accepted this portrayal, although during the period of the brief, failed Oslo Accords it was toned down. (Pappe 2014, 28)

These images of Palestinians as terrorists are deeply rooted in the Zionist agenda, as well as in the historical memory of many Jewish Israeli citizens.

The socio-political religious conflict between Palestine and Israel creates significant tension and disagreement; one thing that is agreed upon is that no one agrees. The situation in both the West Bank and Gaza is both dire and ambiguous and there is no clear, easily agreeable solution about what can be done to bring a lasting peace to the region. While opinions differ on both the history and present reality on the ground in both Israel proper and the occupied territories, the truth is that, since the Nakba, or catastrophe, of the Israeli war against the Palestinian people in 1948, Palestine has been shrinking.

\section{HISTORY}

In order to understand the present reality within Israel/Palestine, knowing the historical background is necessary. Before diving into this complicated web, a few terms must be clarified. Palestine refers to the historic land that exists in the region. Palestinians are the nonJewish, Arab community living inside both Israel proper and inside the West Bank and Gaza. The Occupied Territories are the lands within this geographic location that have been illegally seized and settled by the modern nation-state of Israel. For the purposes of this chapter, the State of Israel will refer to the current and modern country, not the ancient nation and biblical people. Additionally, there is a difference between Judaism and political Zionism that impacts how the politics of the region are understood. Judaism is a religious tradition that is based upon the Hebrew Bible scriptures and tradition. Zionism is a political movement to create a Jewish homeland. Theodor Herzl proposed that this political strategy would be the solu- 


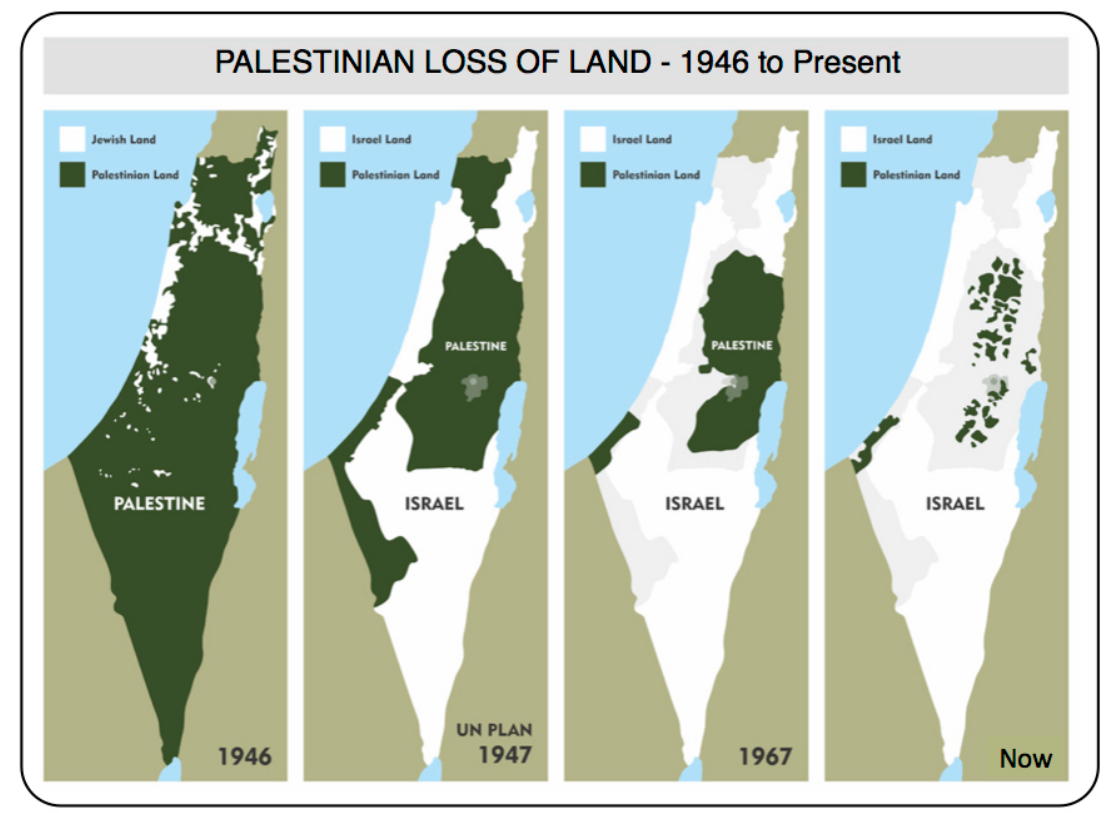

FIGURE 1: Image of shrinking Palestinian territory (Israel Palestine Mission Network, new.israelpalestinemissionnetwork.org/study-resources/maps).

tion for both anti-Semitism and Jewish secular culture. "It is impossible to discuss the realities of the West Bank situation and what this means for Palestinians without reference to Israel's political ideology of Zionism ... the objective of Zionism from the beginning has been to take control for the Jewish people, as much of the land of Palestine with as few non-Jewish natives there as possible" (Christison 2008, 33). Political Zionism is the ideology at the center of the dehumanization of the Palestinian people.

Zionism was European Jewry's response to the devastating effects of anti-Semitism and, in particular, to the despair at the failure of the Enlightenment to confer rights and equality to the Jews of Europe. The Zionist national movement was driven as much by a fierce need for dignity and self-determination as by a feeling of physical vulnerability. Modern Israel is, more than anything, a source of pride for Jews: it is good to have survived, and Israel is the proof of our survival (Braverman 2010, 55).

Zionism has been a tool that modern-day Israel uses as a way to ensure that the Jewish culture, faith, and religious story is kept alive. It is important to differentiate between the religion of Judaism and 
the political movement of Zionism when beginning to understand the current lived reality for the human beings that live on this land.

One popular narrative within the Zionist movement is that there were no people living in historic Palestine prior to the British mandate (Pappe 2014, 29). The case is often made that the Jewish people, migrating after horrific persecution in Europe, came to an uninhabited land. This popular story is utterly false. Historically, non-Jewish Arab peoples of multiple religious traditions and ethnic backgrounds have been calling Palestine home for centuries. The Arab population in Palestine is descended from people who lived in the area during the mandate period, and in many cases, for centuries prior. The Arabs of Palestine have always overwhelmingly been opposed to a Jewish state, or to large-scale Jewish immigration, which has often led to their dispossession from their lands. Contrary to popular Zionist opinions, Palestinian culture existed in historic Palestine before the first wave of Holocaust-surviving Jews migrated to the region.

While there was a small community of Jews living in historic Palestine, they were the minority. By the 1920s, Palestinian culture had experienced a renaissance of sorts and started to mass produce literature and cinema, and it boasted a wealthy aristocratic class. According to Jewish Israeli historian Ilan Pappe, many Palestinians were wealthy in terms of assets and education (Brunner 2011). By 1840 Palestine had reverted back to a part of the Ottoman empire and was opened up to the British, Austrians, and Russians that came to the aid of the Ottomans. This increased international interest in Palestine led to the creation of consulates in Jerusalem and ports in Palestine's coastal cities. The Ottoman Land Law of 1858 led to the development of private property, agricultural production for the world market, the decline of tribal social organization, growth of the population, and the enrichment of the noble families. The Ottomans extended their military, municipal, judicial, and educational systems to Palestine, which brought marked increases in foreign settlements. By 1919, the population of Palestine was majority Muslim at 535,000, with about 70,000 mostly Arab Christians and around 85,000 Jews.

Even though it was dissolved in 1934, the brief life of the Arab Executive Committee, born out of the December 1920 congress in Haifa, left a legacy that held Arabs in their deserved social standing until 1948. This basic policy, which set the position that Palestine was an autonomous Arab entity and rejected any rights of the Jews 
in Palestine to taking the land, was held in place until the Zionists moved for war in 1948. The Arab Revolt of 1936-39 was the first sustained act of violence by Arab Palestinians and caught the British off guard. Thousands of Arabs from all walks of life were mobilized with a sense of nationalism that was spread into the activities of literary circles, the press, and schools. Although it signaled the birth of national identity, the revolt was unsuccessful in many ways. Their traditional leaders were either killed, arrested, or deported, leaving the remaining population divided, dispirited, and disarmed.

The period during the Second World War in Europe allowed for the building up of a Jewish contingency in the area that would eventually lead to the military takeover of Palestine. One final critical factor that is important is the influence that the Holocaust has had on the historical narrative and collective memories of the Jewish population in the modern State of Israel. Fleeing Europe after incredible horror, death, and catastrophe, the Jewish people came to the British Mandate of Palestine after the war in hopes of finding solace in their traditional homeland. For many Jews, the Holocaust killed their faith. For others, the Holocaust killed their Jewish identity. Yet, for most, it sparked a deep desire to reclaim whatever identity and history they could in order to solidify their ethnic, cultural, and religious identity as Jews.

Unlike much of the planet, the geographic space within the area of Israel and Palestine boasts a long and complicated history that is intrinsically connected to three different religious traditions. It is impossible to discuss and understand the current struggle in the Holy Land today if you are unaware of the biblical history of the land. It is also impossible to learn about the modern conflict if avoiding religious and political discourse is a primary objective. Religious narratives are tied to places, people are tied to their religious narratives, and, as such, people become tied to the land in which these stories happened. It becomes complicated when there are three valid religious traditions that all have valid claims to space and place within Israel and Palestine.

Three major world religions-Christianity, Islam, and Judaism, are all tied to the historic land of Palestine. For Christians, Palestine was the place where Jesus was born, lived, and walked out his ministry. Jewish people are connected to the land because the biblical narrative of the Israelite people in the Hebrew Bible occurs in the geographic region of what is now known as modern-day Israel, 
Egypt, and Jordan. For both Christians and Jews, factually knowing whether or not the story of the Bible happened or not is of little importance. What is important is the belief in the story. For Muslims, Jerusalem is the site where Muhammad rose to heaven and was given, by Allah, the second pillar of Islam - to pray five times a day. Each of these traditions have a legitimate claim to the importance of this land to their faith. In a perfect world, these three communities would be able to live peacefully with one another. Yet, the world is not perfect and fighting for the right to both space and place has been at the core of how the modern conflict has developed. Beliefs are powerful. Beliefs mixed with ingrained prejudice are dangerous. "The ideology that enabled the depopulation of half of Palestine's native people in 1948 is still alive and continues to drive the inexorable, sometimes indiscernible, cleansing of those Palestinians who live there today" (Pappe 2006, 259). In 2019, the Zionist agenda to take over more land for the Jewish homeland, coupled with the idea that all Palestinians are terrorists, is still projecting its ugly voice into the lived lives of both Israeli Jews, non-Jewish Israelis, and those living in the occupied territories.

For many Israeli Jews, the memory of the Holocaust is still a large part of the collective narrative. "The protection of the Holocaust memory in Israel from any critique is consensual and widespread" (Pappe 2014, 153). Still today, anyone who speaks out against the actions of the political state of Israel is, more often than not, slandered with anti-Semitic rhetoric. To be critical of the Israeli government equals anti-Semitic thoughts. According to Yehuda Elkana, an academic who was imprisoned in Auschwitz at the age of ten, Israelis harbor an exaggerated sense of themselves as victims and, in his view, it is this self-image that prevents them [Jewish Israel] from seeing the Palestinians in a "more reasonable light." Elkana stated that Israel would use this image of perpetual victimhood to "justify the crudest behaviour to the Palestinians" and would end up "mimicking the behaviour of the worst of their enemies [Hitler]" (Pappe 2014, 157). While the world should never forget the atrocities and violence against the Jews that occurred in Europe during World War II, it cannot be kept alive to justify cruelty against another community. 


\section{THE GREAT BOOK ROBBERY}

During his postdoctoral studies, historian Gish Amit uncovered a story that had been hidden for decades. His larger doctoral dissertation, "The Jewish National and University Library 1945-1955: The Transfer to Israel of Holocaust Victims' Books, the Appropriation of Books of Jewish Emigrants from the East, and the Collection of Palestinian Books during the 1948 War" (2010), describes the process of how Israeli forces, both military and civil, worked together to destroy what Ilan Pappe describes as the "Palestinian narrative." Amit's writing suggests that the efforts of the early modern State of Israel were to both save the books which may not have been preserved and to simultaneously destroy any trace of Palestinian cultural heritage. He points to numerous primary source documents, mostly in Hebrew, that show a paper trail that indicates that the 1948-49 collecting of Palestinian books was unlikely to have been done out of pure good intentions. One of the former Jewish Israeli librarians that was interviewed in the film mentions that these books were taken to be safe-guarded with every intention of being returned to the owners. However, the reality is that even when the children and grandchildren of the original owners come looking for their families' precious items, it becomes clear that the Israeli National Library never had, and likely never will have, an intention of returning the stolen books.

During the period between May 1948 and February 1949, the staff of the Jewish National and University Library at Hebrew University collected approximately 30,000 volumes (books, manuscripts, journals, newspapers, etc.) that were left behind by Palestinians as they were forcibly removed from their homelands due to the ongoing war. Additionally, in the years following 1948, the newly developed Custodian of Absentee Property gathered around 40,000-50,000 books from other Palestinian cities and lands-many of these books were textbooks originally belonging to British mandate schools that were later sold for profit to Arab schools. Some 26,000 books were deemed "unsuitable" for Arab schools inside the new State of Israel due to their content and were sold as paper waste. Amit $(2008,8)$ speaks to the important reality that occupation is not just about overtaking physical space; it is also about rendering the culture of the loser lifeless. "Palestinian books were placed within the shrine of Israeli libraries, fossilized on the shelves-accessible and at the same time completely lifeless." Little research has been done on the effects of the war on Palestinian culture, and Amit's contribution is 
a good representation of what should and must be an ongoing effort in the future.

The Great Book Robbery is a provocative film that should be widely watched. It brings light to a story that was kept away from the light in order to conceal the morally murky dealings of Israel as it began to be formed. As the film suggests, the operation of collecting Palestinian libraries was both an effort to exclude Palestinians from the national collective, which was to be entirely and solely Jewish, and a realization of Zionism's self-conceptualization as an active agent whose mission was moral - to bring enlightenment to the Middle East, making it an outpost of Europe. The notion that modern Israel is the only, and last standing, democratic society in the Middle East denies any responsibility that Israel should have over the atrocious and illegal actions it has taken towards the Palestinian people. This denial-this sentiment that Israel has not acted in any kind of problematic behavior-allows for the Israeli government to continue to break down the Palestinians' sense of personhood, collective voice, and national identity. The thoughts and actions that surround Israel — that they are the victims, engulfed on all sides by Palestinian terrorists-is a distorted message that corrupts the way information reaches the occupied territories, access to information within the occupied territories, and the type of story that comes out of the occupied territories.

\section{TYPES OF LIBRARIES}

\section{National}

There is not a national library in Palestine, because Palestine has not been given de facto statehood. The only national library in the area is the Israeli National Library, which exists in Jerusalem at Hebrew University. The Israeli National Library contains a large collection of Palestinian materials that were acquired during the 1968-69 period of war. This collection includes manuscripts on subjects including the Islamic faith and law, Palestinian history, the history of the Arab world, fictional literary works, and non-fiction books. The staff of the National Library of Israel says that the collection of Palestinian manuscripts and books, "left" in 1948, numbers about 6,477 titles, and these items are cataloged in the library as "AP," or abandoned property (Aderet 2015, 6). “The fact that the library didn't bring to the 
public's attention the affair of collecting or theft ... and the fact that these manuscripts remained in the library's storage rooms without any active effort by the library to return the books to their owners-these are the most disturbing and problematic sides of the affair" (Aderet 2015 , 3). Depending on the source, the acquisition of these resources was either done out of a desire to save and protect these items from damage or it was an intentional action to erase evidence of Palestinian culture and to decimate the Palestinian narrative.

During his research, Amit came across more records of gathering books between 1945-55 and states that the Zionist movement "denied the cultural heritage of other groups in Israel by taking possession of their intellectual treasurers" (Aderet 2015, 6). As Amit notes, "On the one hand, the books were collected and not burned or left in the abandoned houses in the Arab neighborhoods that had been emptied... had they not been collected their fate would have been sealed-not a trace of them would remain ... The National Library ... protected the books from the war..." (Aderet 2015, 4). Whether they were preserved or stolen, a large amount of Palestinian-owned titles remains locked away in the rare books area of the Israeli National Library with little to no access given to those of Palestinian heritage. "For example, the Israeli State Archives, located in Jerusalem, are not accessible to Palestinians from the West Bank who may not be allowed to cross checkpoints, and certainly not to those in the Gaza Strip to whom the border is closed entirely" (Kuntz 2013, 5). Restricting movement to Palestinians in Israel and the occupied territories has become the norm. Even though Jerusalem and Bethlehem are separated by only four miles, the trip between the two can often take two to three hours. If a Palestinian residing in Jerusalem, or a Palestinian residing in the West Bank, do not have the appropriate paperwork and permits, they are denied access through the checkpoints. Even if someone possesses proof that they need a permit, Israel often denies these requests, which effectively traps Palestinians within the confinements of their neighborhood. The wall checkpoints that prohibit Palestinians from being able to access their historical narratives, memories that keep culture alive, is a violent form of apartheid practice.

Not only has the Israeli National Library practiced the perpetual borrowing and "protection" of Palestinian abandoned property, it has 
also acquired, without permission, titles from non-European Jews who immigrate to the country.

Rabbi Yehiel Umassi, a Yemenite spiritual leader who immigrated in 1950, told about one such incident. Before boarding the plane, he entrusted 10 of the community's Torah scrolls to a man from the Jewish Agency. When he showed up to pick them up from the JA's storehouses in Tel Aviv, they weren't there. In a letter that year to the agency, he wrote: "Upon their arrival ... the parcels were unwrapped, the crates broken, the sacks were torn and the books with valuable things were stolen" (Aderet 2015, 3).

To date, there are approximately 430 Yemenite manuscripts held in the National Library of Israel. For the owners of these precious and valuable items, of both Palestinian and Yemenite belonging, the items were taken while the owners were not present and without their permission. Prominent Christian Arab teacher Khalil Sakakini, who died in 1953, describes his sorrow with these words: "Farewell, my chosen, inestimable dear books. I do not know what your fate has been after we left. Were you plundered? Were you burned? Were you transferred, with precious respect, to a public or private library?" (Aderet 2015, 5). Until 1950, items in the abandoned property classification, particularly those seized from Palestinian homes and institutions, within the library were cataloged by owners' surnames, making it easier to track original ownership. However, since the 1960s they have been catalogued only with the "AP" designation and it seems that the Israeli Custodian of Absentee Property and the National Library have no plans to return them to the descendants of their rightful owners.

\section{Public}

When you walk into a library or cultural center in the West Bank, you walk across tracks left by military tanks that crush street and sidewalk pavements, smash cars, and eat parts of fences and homes ... as you step into one of these little heavens, you are surrounded by organized space, colored paintings on the walls, posters. And you appreciate the quiet, the quiet we amuse ourselves with here when we associate a librarian with "sssshhhhh." - Ghada Elturk (2002)

Abu Salma Public Library in Nazareth originally opened in 1980 or 1981 in an old house. Nazareth is the only majority-Palestinian city within Israel proper and the library serves over 100,000 patrons 


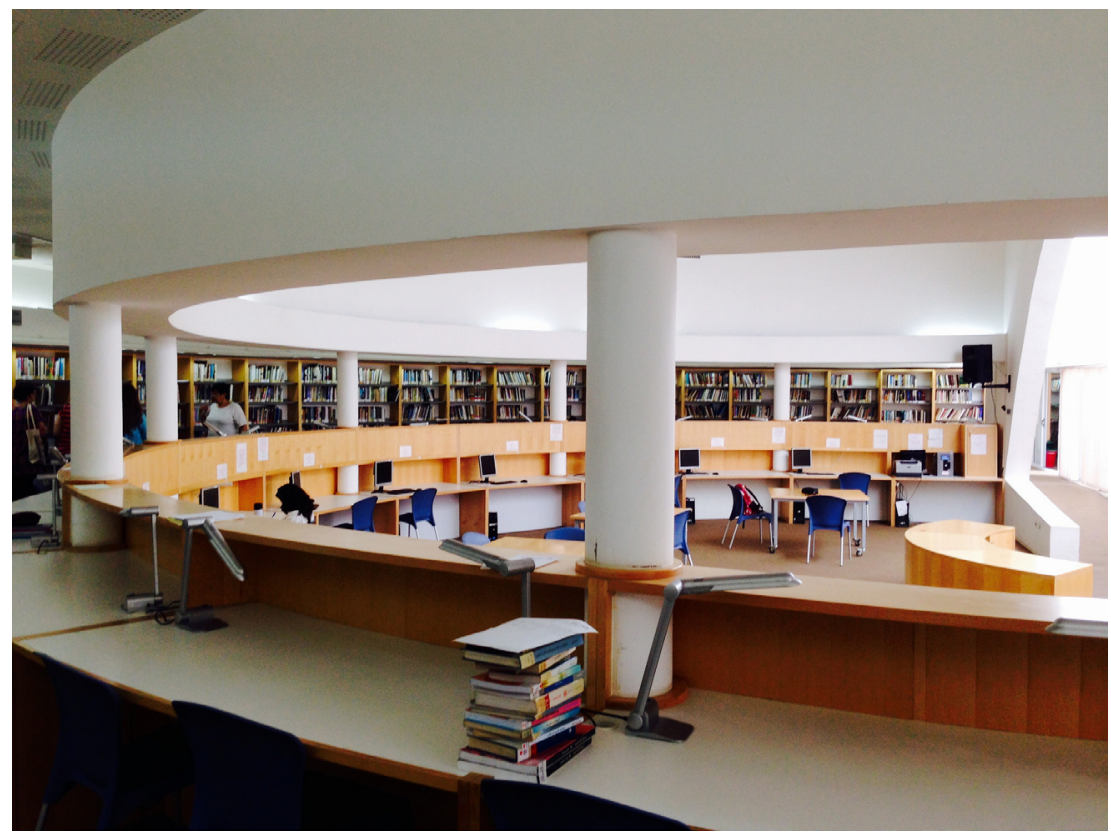

FIGURE 2: Abu Salma Public Library (Librarians with Palestine, librarianswithpalestine.org/featured-projects-members/public-libraries/abu-salmapublic-library/).

from the city, as well as the surrounding villages. The library collection here is mostly academic titles with some fiction and non-fiction works in Arabic, English, and Hebrew. As in other areas inside Israel proper, the West Bank, and Gaza, library funds are usually the first thing to get cut from budgets. Funding for building maintenance comes from the municipality in the form of taxes, yet the funding for books, computers, and programs comes from the Israeli government. Government funding is based on the amount of library staff on location. In Nazareth there are currently four positions, filled by six staff members, who are doing the work of eleven (Librarians for Palestine). This artificially low headcount results in low funding. Books are expensive and, due to the lack of funds, maintaining an updated collection is nearly impossible. Instead of being given cash for acquisition purchases, the librarians are given credits that can only be used at certain government-approved vendors. However, in order to navigate around this official system and be able to purchase from other vendors, there is an unofficial system that is utilized. There is a chain of people that works to get these titles, however, by the 
time the process is said and done, four to five people have handled the materials-all wanting a five to ten percent fee for their labors.

In Palestine, the public libraries function as centers for political resistance to the occupation.

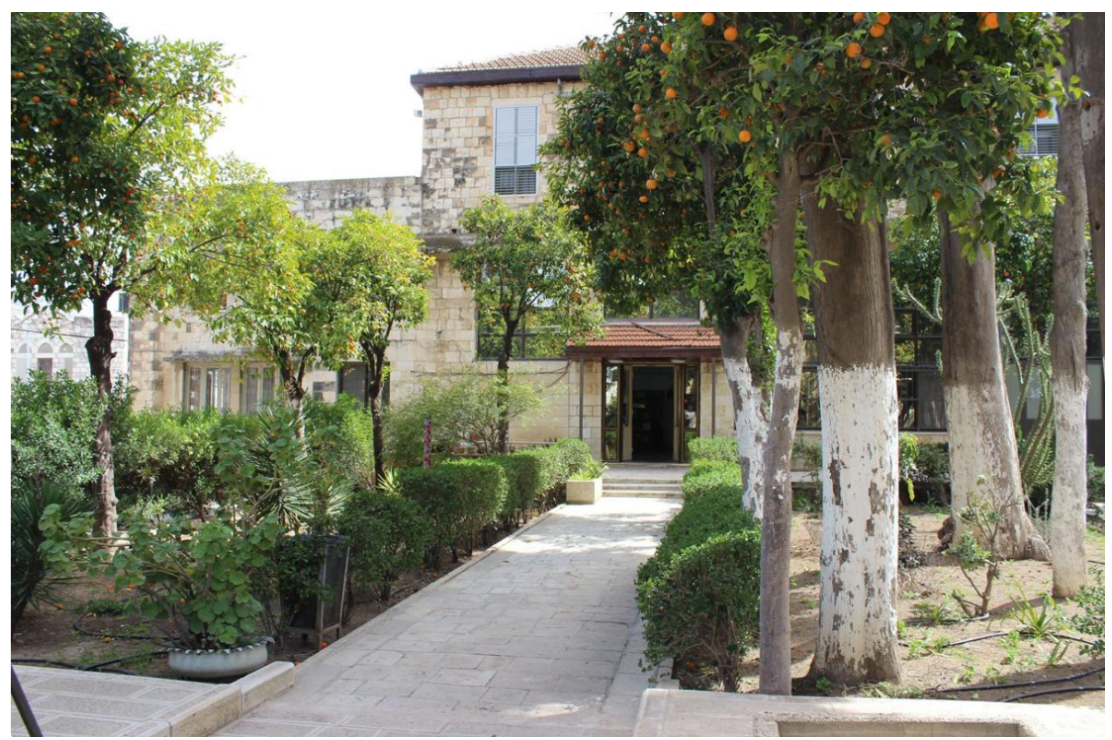

FIGURE 3: The Nablus Municipality Library (www.mahmiyat.ps/en/ecoTourism/215).

The Nablus Public Library first opened its doors in 1960 and is the largest public library in Palestine. According to Librarians with Palestine, the Nablus municipality provides a budget for the library, but there is not enough to support collections development. In order to develop the collection, they largely depend on donations from universities and they purchase books from local sellers. One major restriction placed on libraries within Palestine is the prohibition of books purchased from Lebanon. Lebanon is a central publishing hub within the Arab world and the ban on books from this country stunts the availability of Arabic voices within the collections' holdings. One of the major contributions that the Nablus Public Library gives to the local and global community is its section on the experiences of Palestinian political prisoners of Israel. This section is an archive made up, and used, by Palestinians that have been imprisoned in Israeli jails. The collection boasts 8,000 volumes of published books as well as 870 notebooks covering the years of 1975-95. So many Palestin- 
ians have been held as political prisoners by Israeli that the prison system has turned into a center of active learning.

When Israel was forced to close the Nablus-area prisons after the Oslo Accords, the books that were formerly held in the small library at the Nablus prison found their way into the hands of the Nablus Municipal Library. This collection is heavily used to reconstruct the story of the Palestinian struggle of the 1970s, 80s, and 90s. The pages of these well-loved and well-read books oftentimes contain notes and other marginalia that were written by prisoners who read them (Librarians for Palestine). In addition to the special collection of materials from prisoners, the Nablus Library also has a Children's Centre.

The Nablus Children's Centre Library was a priority for the community. The library serves as an entry point for all users and has a collection of materials for children ages six to sixteen. There is one librarian on staff with other trained personnel that assist as needed. The collection of 6,000 items does not circulate, in an effort to keep the materials in good condition. The center holds a weekly event where mothers can read to their children aged three to five (too young for kindergarten) and become more familiar with the library. The mission of this children's library is to continue pursuits that will foster learning about Palestinian culture and center the importance of education. Unfortunately, since the second Intifada (2000-05), the library has been unable to add any new materials to their collection due to tightened restrictions.

The Al-Bireh Public Library near Ramallah is a vibrant and important center of culture and learning inside the West Bank. After the library was bombed by the Israeli invasion, just after its opening in 1967, the library has become a space for popular education, folklore, transmission of Palestinian culture, and politicization (Natarajan and Mermelstein 2014, 250-4). The library offers access seven days a week and has a collection of around 50,000 volumes. Al-Bireh Public Library was first founded in an apartment with warplanes circling overhead, as one librarian recalls, and is intrinsically tied with the resistance movement (Librarians for Palestine). In addition to providing access to books, the staff provide field trips to help assist in olive harvesting and planting as part of its initiative for youth library service. Like other libraries within Palestine, it is increasingly difficult for Al-Bireh to develop their collections. By 1993, over 5,000 titles were banned by Israel and the strict ban on items coming from 
Lebanon means that most of the collection that they do hold is of lower quality. In a 2013 interview, librarian Hamsa el-Said recalled that being a librarian within the setting of an occupation means to struggle daily with colonialism and oppression. To him, the role of the librarian is to work to preserve the Palestinian national identity and culture and to de-colonize the feelings that Palestinians have about themselves. He encourages the users of his library to be both active agents of change and engaged readers. He says that people should never trust a book and he encourages them to be critical of what they read. In addition to working towards library literacy, he works to create cultural activities that foster community building and a sense of identity among the Palestinians within his community. In addition to reaching the community outside the doors of the library, the library works with those confined in the walls of Israeli prisons. They donate items to prisons even though the Israeli authorities confiscate many materials in their efforts to keep prisoners uninformed and uneducated. However, this does not stop Al-Bireh Library from doing what it can to open the minds of the people being held captive

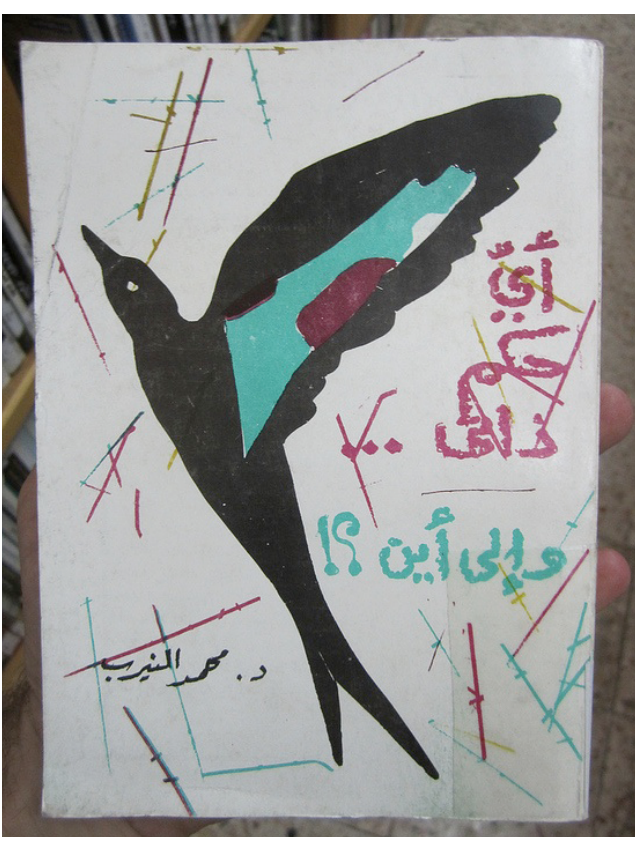

FIGURE 4: A photo of a book cover in the collection at Al-Bireh Public Library (Librarians with Palestine. librarianswithpalestine.org/wpcontent/uploads/2014/06/al-birah-book.jpg). by the Israeli military.

On Thursday, August 9, 2018 the Al-Meshal Cultural Center in Gaza was bombed by Israeli forces. This five-story building housed a theatre for arts and dabke, an Egyptian community center, various cultural association offices, and a library. For residents of Gaza, this establishment was more than just a building. The center was a cultural landmark and was where memories were kept. The center was a place where life and connection could exist within an already 
isolated and cut-off community. Even though the Israeli Defense Force (IDF) noted that they were aware that the center was used for civilian affairs, because of reports about Hamas activity within the building they targeted it nonetheless. Due to construction restrictions, permit issues, and lack of money and supplies, the center has not been able to be rebuilt. Much of Gaza lies in rubble, as re-building is thwarted on all sides by Israel. Violence is nothing new for Arab communities living within the walls of the occupied territories, and it unfortunately does not look like there is an end in sight. Yet libraries and librarians within Palestine do the best they can to keep hope alive.

\section{Academic}

Al-Quds University is a Palestinian University with several campuses located in Jerusalem, Al-Bireh, and Abu Dis. Like all Palestinian libraries within the occupied territories and inside Israel proper, procuring funding for books and resources is a constant challenge. In addition to the financial strains, the Israeli government controls materials moving across the Israeli border. While donations are sometimes helpful, they are also a detriment to the collection development process. In one instance, $\mathrm{Al}$-Quds received a charitable donation of 30,000 volumes and, after sorting through them, it was decided that only three to four hundred titles would be beneficial to the collection (Librarians for Palestine).

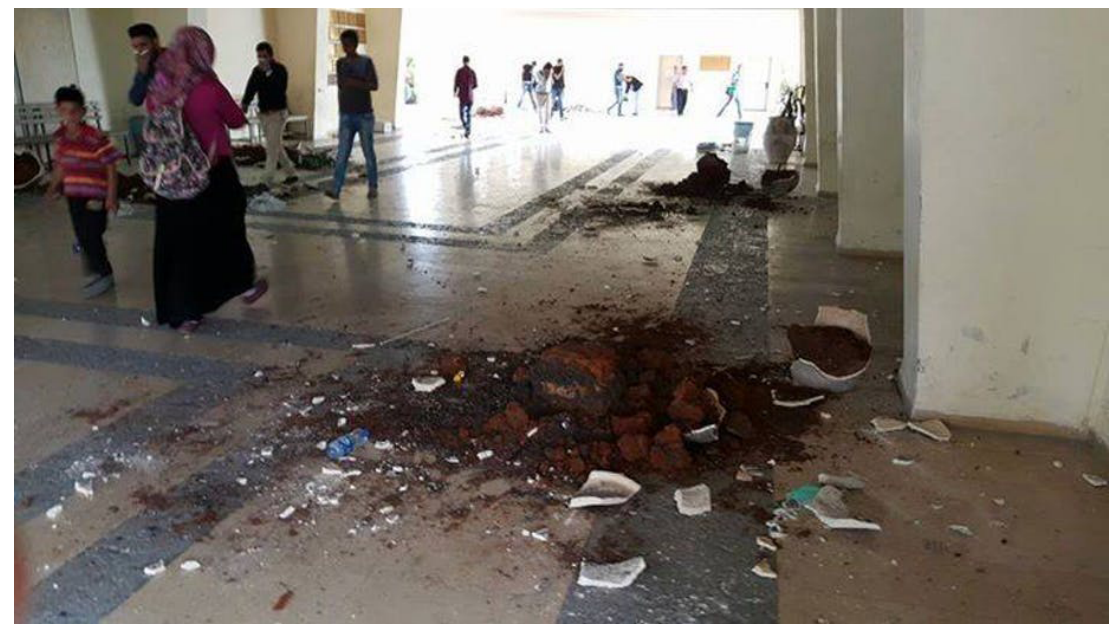

FIGURE 5: Damage to Al Quds campus in the Abu Deis suburb of Jerusalem following an October raid (theconversation.com/education-under-occupationeveryday-disruption-at-a-palestinian-university-49035). 
In addition to funding and collections issues, the Al-Quds campuses have been a hot spot for Israeli military aggression. With routine attacks from 2012-14, 2016, and most recently in 2018, the university closed multiple times, affecting students' learning and access to the libraries on campus. One of the goals of the military occupation is to relentlessly attack institutions of higher learning, and Al-Quds is at the center of these acts of violence. Universities in the West Bank and Gaza are key incubators of the resistance and major channels of Palestinians' aspirations for freedom and justice (Reimer 2018, 1). Students are at the front lines of the Palestinian resistance and are often held at checkpoints for several hours while trying to travel from home to class and vice versa. Movement is heavily restricted for Palestinian students living in the West Bank and for those in Gaza, they are living in an open-air prison. During Israel's 2014 war on Gaza, 66\% of students at Al-Quds University lost their homes. "The scars left on Gazan students are a graphic illustration of the deeper reality of Palestine as a whole: the progressive amputation of universities is central to Israel's intentions" (Reimer 2018, 1-2). Yet, despite all of Israel's attempts to destroy education for Palestinians, it is one among a few things that the populations of Gaza and the West Bank have left. Given Israel's continued blockade of Palestinian universities, it is no surprise that Palestine, by international standards, has a high rate of participation on tertiary education.

Birzeit University Library is currently facing collections development issues due to the continued confiscation of books and other materials by Israeli customs and border control. As Diana SayejNaser said in an interview during the 2016 American Library Association conference in Orlando, "we have issues with getting books from outside the country, especially from the Arab world. A few are confiscated due to their titles. Sometimes the title is a key to confiscating the book." In addition to books being held by customs, students are often held at the interior checkpoints for carrying books that belong to the university. Sayej-Naser notes that many of the library's books have been lost to the Israeli military as students attempt to pass through checkpoints.

Like Al-Quds, Birzeit is no stranger to military violence. On March 8,2018 , armed Israeli soldiers disguised as students made a violent intrusion onto the Birzeit campus - the fifth such incident in just two years-and kidnapped the head of the student council. During the struggle, live rounds were fired (Reimer 2018, 3). Sadly, the violence 
does not end with physical assaults on campuses, students, faculty, and staff at Palestinian universities. The universities are structurally undermined as the crippled economies of the West Bank and Gaza cannot produce the tuition fees necessary to fund university budgets.

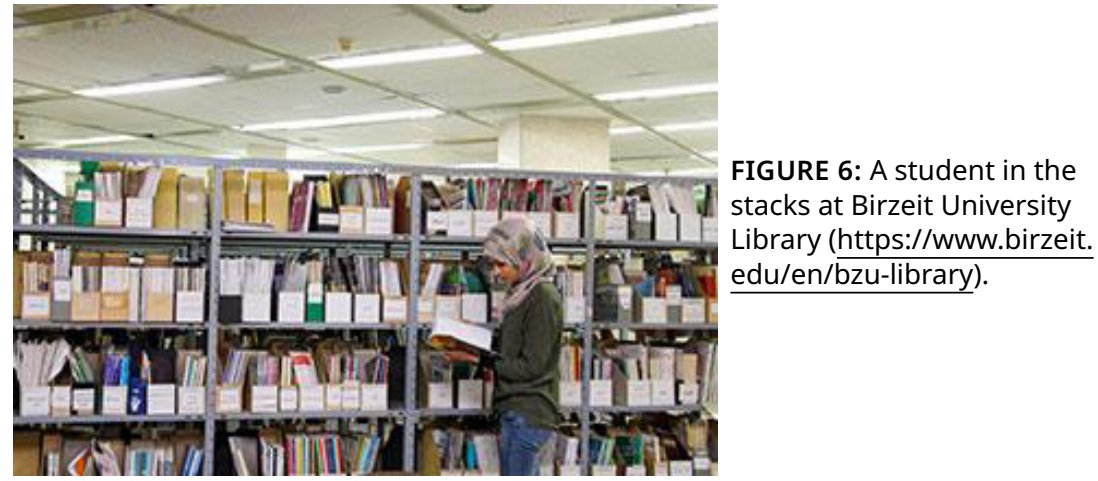

Furthermore, tightening Israeli regulations on foreign work visas and the near impossibility of academic freedom makes it hard for these universities to attract international faculty and staff. Between the high rates of visa denials and the increased violence on higher education centers, Palestine is an unpopular destination for academics and library professionals. This leaves many Palestinian universities siloed in local enclaves, desperate for international contacts and resources. While university staff, faculty, and students have it difficult, it is far harder for primary and secondary schools to acquire the necessary supplies to allow for adequate libraries and learning for students.

\section{School}

Unfortunately, there are no studies or objective data to inform judgement about the quality of education or skills imparted on children living under the occupation (Abu-Duhou 1996, 3). However, both government- and humanitarian-run schools inside the West Bank and Gaza do not have the funds or resources to have libraries for their students. While the West Bank generally fares better than Gaza, each location has problems. In Gaza, there are not enough books for Gazans in general. The entire holdings of all open and functional libraries is 70,000 volumes for over 1.8 million people. In many instances, just having a building to learn, read, and teach in is a hard-enough reality. In 2014, 258 schools were damaged when Israel 
waged war against Gaza. Making things more difficult, the current US Administration has blocked funding for several US-based funding projects to restore schools, water, and sewer systems in Gaza. With severely high unemployment rates, utterly damaged spaces that are unable to be rebuilt, and a broken economy, the possibility of libraries in Gaza for school-aged children is a dream.

However, not all hope is lost. Mosab Abu Toha, a young Gazan with a degree in English literature, has been unable to travel the world except through books. He and his friend Shafi Salem have collected hundreds of books (currently housed in Mosab's apartment) with the dream of opening a library, with a bookshop and café, in a building of its own (Pollit 2017, 2). Among donors to this growing collection is Noam Chomsky, who says that, "It has been amazing, and inspiring, to see how people surviving in the Gaza prison, subject to constant and vicious attacks and living under conditions of brutal deprivation, continue to maintain their dignity and commitment to a better life" (Polit 2017, 3). Amidst the harsh conditions imposed by Israel on Gaza, the Palestinian people living here still maintain and keep hope alive.

In the West Bank, the stories of school libraries are reflected in the few anecdotes shared by librarians in a video edited by Rachel Mattson (2016). They each discuss the various struggles facing their schools. One librarian, who works in a school for seventh through twelfth grades, discusses how her library was burned three years earlier and they have yet to rebuild. Another librarian speaks to the importance of working as best she can with various colleagues to turn libraries into cultural centers, available to everyone. The last librarian in this video discusses how the school library functions not just as a space for school children, but also as a center of learning and education for adults and families in the wider community.

In addition to the lack of adequate libraries for schools in the West Bank and in Gaza, the seventy Arab schools within the 1948 borders of Israel have to adhere to specific policies and regulations regarding education and access to information. Books on several topics are prohibited in the schools, including information regarding the Palestinian Liberation Organization (PLO), and any subject dealing with Palestinian culture and history is not allowed to be taught in the school system (Kuntz 2013, 8). The Israeli curriculum is a form of propaganda and has strict regulations about what can be taught and how it can be taught. Working against the set curriculum can 
be dangerous for schools, yet almost all non-Jewish Israeli schools do what they can to challenge the dominant, pro-Zionist, narrative that Israel constructs.

You can even make beauty from stones that put a bump in your way.

- Johann von Goethe

The Carmelite School is a private religious school located in Haifa, inside the borders of the modern Israeli state. The school serves the first through twelfth grades and has a collection of about 6,000 volumes. Each year the school has a book march, or book club, where the librarian chooses texts of good quality and high appeal for the students to read and discuss. At the end of the term, there is a celebration that includes writing, art, and theatre. This yearly event encourages students to read individually and collectively, and at the end they choose their favorite book from that year's selections. The school is now managed by a Franciscan friar and sits near the foot of Mount Carmel. Haifa is a unique place within the borders of modern Israel. It is known for its peacefulness, religious tolerance, and apolitical nature (Librarians for Palestine). This may be because the city is diverse and most of the Jewish residents are immigrants from the former Soviet Union. While the school is run by Christians and has a high percentage of students that identify as Christian, there are also students who identify as Druze and Muslim. The school hopes to create a clear path and sense of urgency for the place of Christians within Israel.

Within Israel, the West Bank, and Gaza, Christians are in the minority. As of 2013 , about $2 \%$ of the population within the borders of Israel proper identified as practicing Christians. Within the occupied territories of Gaza and the West Bank, there are approximately 50,000 Christians, most of whom self-identify as Palestinian Arabs and live within the West Bank. The world often forgets that Christians exist within Israel and Palestine, and theologian scholar writers like Mitri Raheb and Naim Ateek invest their energies in making sure that the world remembers. A discussion of schools and institutions working to keep the Palestinian spirit alive would be incomplete without the mention of the Diyar Consortium in Bethlehem. Diyar began in 1995 and was founded as the International Center in Bethlehem, aiming to assist people living under occupation to be able to creatively resist. Today it functions as a consortium of Lutheran-based, ecumenically focused institutions that serves all 
Palestinians from "the womb to the tomb." Diyar's mission is to "build a country, stone by stone; to empower a community, person by person; to create institutions that give life in abundance." Provided programs support the formation, development, and reinforcement of Palestinian culture and identity through the arts, music, theatre, dance, sports, book publishing, and media productions. Now retired, the Rev. Dr. Mitri Raheb, who served as the president of Diyar, the Dar al-Kalima University College in Bethlehem, and the senior pastor at Christmas Lutheran Church in Bethlehem, was also the chief editor of one of the initiatives of Diyar Publishing. Through their publishing arm, the central purpose of Diyar is to make sure that Palestine and Palestinians remain alive in an environment that is perpetually trying to crush the spirit of the people.

\section{Special}

Al-Budeiri Family Library is a small private library and archives located in the Old City of Jerusalem. Its collection includes about 900 manuscripts dating back to the 12th century C.E. The library's collection sprung out of the personal holdings of Sufi scholar Sheikh Muhammad Ibn Budair, known as Ibn al-Hubaysh. He was a prolific writer and authored a number of literary works, most notably a poem written about the defeat of Napoleon before the walls of 'Akka in 1799. According to the Palestinian American Research Center, roughly half of the library's manuscripts are well-preserved, with another quarter needing only rebinding (by

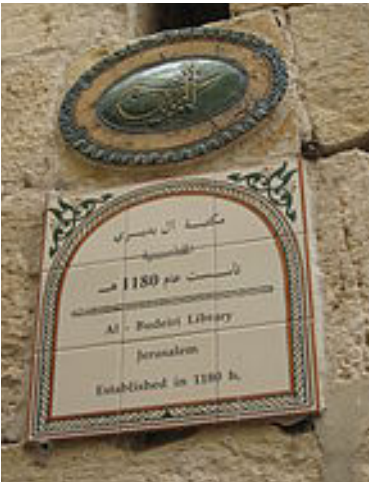

FIGURE 7: The sign at Al-Budeiri Family Library (wikivisually.com/wiki/Al-

Budeiri_Library). Islamic experts), and the remainder in total or partial disrepair. The library is still run by the family out of the home of al-Hubaysh, as noted in his will. It is open to the public by appointment only.

Khalidi Family Library is perhaps the largest manuscript collection within Palestine, with more than 2,000 titles. The collection has developed over the years through a series of gifts and it includes thousands of titles in Arabic, English, French, and Turkish. While a majority of the holdings are on the subject of the history of the Islamic religion, there is a sizable holding of manuscripts that are on the topic of the history of Palestine. There are also a number of 
rare manuscripts that are considered originals, with 112 manu-

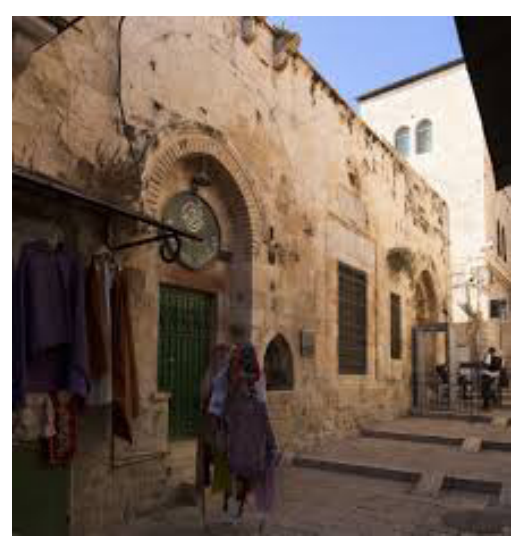

FIGURE 8: Khalidi Family Library (Wikipedia). scripts written in the handwriting of the author. While the Khalidi Library is open to the public, the demographic that it serves most frequently is researchers.

The Issaf Nashashibi Center for Culture and Literature holds some of the best-preserved manuscripts. In addition to the holdings of books and manuscripts, there is a collection of newspapers that date back to 1967. The collection is housed in the home of the late Palestinian literary figure Is'af al-Nashashibi. Ownership of the property was officially transferred to the Dar Al-Tifl al-Arabi Institution, founded by Hind al-Husayni, who knew the importance of maintaining manuscripts for the survival of Palestinian heritage. Like many Palestinian libraries within Jerusalem, the West Bank, and Gaza, the Nashashibi Center is in need of an online computer cataloging system. However, this does not stop the library from serving 50-100 patrons each week (Palestinian American Research Center).

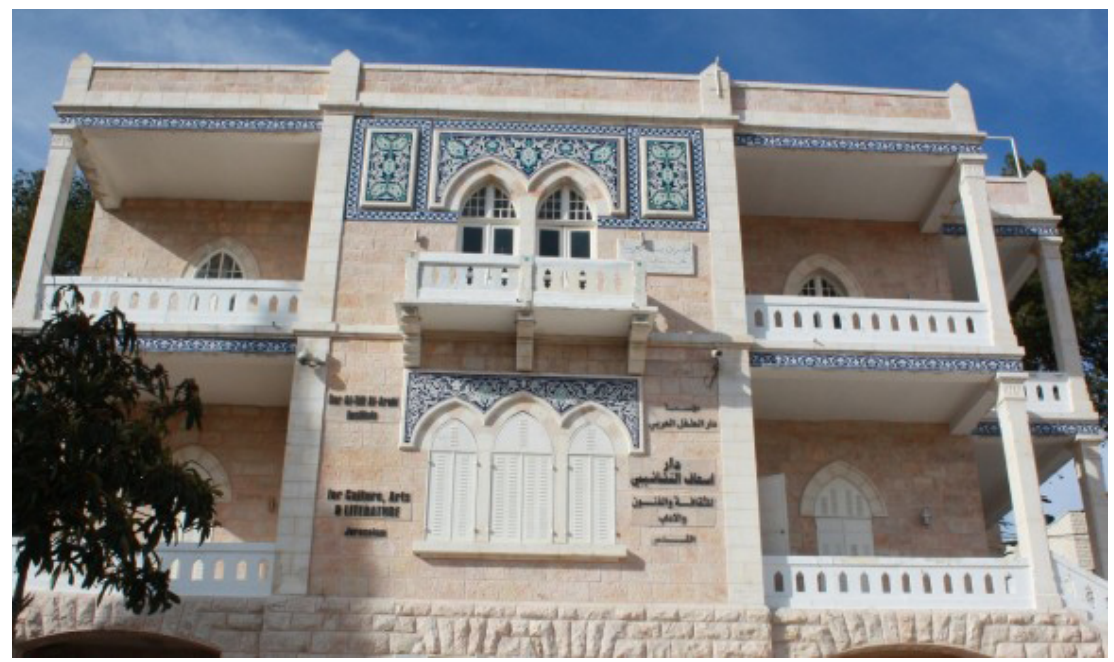

FIGURE 9: Issaf Nashashibi Center. 


\section{Library and Information Science Education}

There are no library school programs or training opportunities available to Palestinians in Palestine. Due to budget issues and travel bans, it is incredibly hard for librarians to receive proper training in Palestine. It is equally difficult for international librarians to get to both the West Bank and Gaza. In general, Gaza has many professionally trained librarians with no access to jobs, and the West Bank has many job openings but no librarians to staff them. Neither location is particularly desirable to live in, and even when international librarians try to come work in Palestine their visa applications are often denied by Israel. "Librarians with MLS degrees are uncommon due to the political unrest in the area, the financial limitations, and the lack of standards for professional employment ... the profession of librarianship is neither recognized nor well-understood in the region" (Eberhart 2016, 1). Librarians at both Birzeit and Al-Quds Universities remark on how difficult it is to establish librarianship as a profession in the West Bank. "There are no post-undergraduate library schools in the West Bank and it is very difficult to find professional librarians and archivists" (Kuntz 2013, 9). In addition to a lack of library professionals, there is no shared catalog for the libraries within the occupied territories. There is no unified Palestinian union library catalog due to the exorbitant expense, and each university must pay to maintain its own catalog. Because of a lack of union catalog and the presence of the apartheid wall, interlibrary loan does not exist. The Israeli checkpoints make movement difficult for Palestinian librarians to attend meetings, so while the Palestinian Library Association exists in theory, in practice it is not allowed to flourish.

Another problem that faces librarians and librarianship within the occupied territories is the "tepid" international response. The International Federation of Libraries and Archives (IFLA) tends to side with US politics and compares Israeli and Palestinian libraries and archives as if they existed on equal footing (Kuntz 2013, 9). This practice denies the continued Israeli destruction and continued harassment of Palestinian libraries and archives. The effects of colonialism and occupation on libraries, archives, and Palestinian society are tangible and should not be ignored by the international community.

While there are no programs for library science in the West Bank and Gaza, there is one program that assists school principals within the West Bank to gain library skills. The Center for Applied Research 
in Education, Occupied Palestinian Territories (CARE Palestine)'s Library Development Programme provides training to equip principals with the necessary skills to run and maintain libraries for their schools. However, as with many internationally funded programs, information on this project is not well maintained, and what information is available is limited and dated.

\section{Library Organizations within Palestine and International Organizations working with Palestine}

In 1994, the Palestine Library Association saw the light of day, but, being subject to restrictions on assembly and movement imposed by the occupying power, it is difficult for it to play a major role in the development of libraries. (Lefebvre-Danset 2009, 2)

Because of the tightened restrictions on movement, the Palestinian Library Association (PLA), and the Palestinian Librarian and Information Consortium (PALICO), the shift of these two associations are to establish academic libraries as educational centers and to advance the professional status of librarians in the area. Mandatory retirement for librarians in Palestine is 65 and, as of 2016, 80\% of the 82 librarians in Palestine are close to this age. In order to advance librarianship, librarians in Palestine mention items that the international community can help promote. These are:

- freely available e-resources (particularly in Arabic),

- funding for local digitization projects,

- training in librarianship,

- scholarships for Palestinian librarians to attend international conferences,

- partnerships with library organizations,

- new books donated directly from publishers,

- for international librarians to travel to Palestine for work, training, and experience.

Randa Kamal makes the comparison between hospitals and libraries, "Just as hospitals treat patients with good medicine, libraries need the best information to serve their communities” (Eberhart 2016, 2). The international community must help Palestinian librarians get the access to information that they need so that the communities of Palestinians, living in illegal occupation, have the best chance of survival. In order to connect with librarians around the world that 
are working in solidarity with Palestine, the following international organizations are a good place to begin:

- Librarians and Archivists for Palestine (LAP)

- American Library Association (ALA) - Social Responsibilities Round Table (SRRT), International Responsibilities Task Force (IRTF)

- The International Federation of Library Associations and Institutions (IFLA) Freedom of Access to Information Freedom of Expression Advisory Committee (FAIFE)

\section{WORKS CITED}

Abu-Duhou, I. 1996. "Schools in Palestine under Occupation and the Palestinian National Authority." Palestine-Israel Journal of Politics, Economics, and Culture 3, no. 1. www.pij.org/articles/566/ schools-in-palestine-under-the-occupation-and-the-palestiniannational-authority.

Aderet, Ofer. 2015. "People of the (Stolen) Book: Did Israel's National Library Engage in Systematic Theft?” Jewish World-Haaretz. www.haaretz.com/jewish/.premium-people-of-the-stolenbook-1.5355614.

Amit, Gish. 2008. "Ownerless Objects? The Story of the Books Palestinians Left Behind in 1948.” Jerusalem Quarterly 33: 7-20.

_. 2010. "The Jewish National and University Library 1945-1955: The Transfer to Israel of Holocaust Victims' Books, the Appropriation of Books of Jewish Emigrants from the East, and the Collection of Palestinian Books during the 1948 War.” PhD diss. Ben-Gurion University.

Braverman, M. 2010. Fatal Embrace: Christians, Jews, and the Search for Peace in the Holy Land. New York: Beaufort Books.

Brunner, Benny, dir. 2011. The Great Book Robbery: Chronicles of a Cultural Destruction, the Story of 70,000 Looted Books. The Netherlands: 2911 Foundation and Xela Films.

Christison, K. 2018. “The West Bank Now.” In Why Palestine Matters: The Struggle to End Colonialism. Louisville, KY: Presbyterian Church (USA) Israel Palestine Mission Network, 33-6. 
Eberhart, George M. 2016. "Academic Libraries in Palestine: Challenges and Frustrations of Information Access in the Palestinian Territories.” American Libraries, June 27, 2016. www.americanlibrariesmagazine.org/blogs.the-scoop/academic-libraries-palestine.

Elturk, G. 2002. "Palestinian Libraries: Little Pieces of Heaven in Hell.” Progressive Librarian 21: 42-8.

Kuntz, B. 2013. "A Report on the Libraries and Archives to Palestine Delegation, June 23-July 4, 2013.” Science for Peace-The Bulletin 33, no. 2: 5-14.

Lefebvre-Danset, F. 2009. "Libraries in Palestine.” Translated by Stephen Parker. IFLA Journal 35, no. 4: 322-34.

Mattson, Rachel. 2016. "Libraries under Occupation: A Conversation with Palestinian Librarians.” Progressive Librarian 45: 113-27.

Natarajan, Vani and Hannah Mermelstein. 2014. "Knowledge, Access, and Resistance: A Conversation on Librarians and Archivists in Palestine." In Informed Agitation: Library and Information Skills in Social Justice Movements and Beyond, edited by Melissa Morrone, 247-60. Sacramento, CA: Library Juice Press.

Pappe, Ilan. 2006. The Ethnic Cleansing of Palestine. London: Oneworld.

- 2014. The Idea of Israel: A History of Power and Knowledge. New York: Verso.

Pollitt, Katha. 2017. "Most of Gaza's libraries Have Been Closed or Destroyed-And You Can Help a New One Get off the Ground." Nation, April 11, 2017. www.thenation.com/article/most-of-gazaslibraries-have-been-closed-or-destroyed-and-you-can-help-anew-one-get-off-the-ground.

Reimer, N. 2018. “The Attack on Palestinian Universities.” Jacobin, December 30, 2018. www.jacobinmag.com/2018/12/palestinianuniversities-higher-eduction-israeli-violence. 